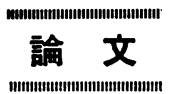

\title{
鉄-りん合金の粒界破壊の炭素による抑制
}

\section{Prevention of the Intergranular Fracture in Iron-Phosphorus Alloys by Carbon}

\author{
Shigeru Suzuki, Minoru Oвata, Kenji AbIKo and Hiroshi Kimura
}

\section{Synopsis:}

$\mathrm{Fe}-\mathrm{P}$ alloys with up to $0.67 \mathrm{wt} \%$ phosphorus show intergranular fracture (IGF) by impact test after quenched from $1073 \mathrm{~K}$. Addition of carbon up to about $0.01 \mathrm{wt} \%$ to the alloys prevents the intergranular fracture caused by the grain boundary segregation of phosphorus, and lowers the ductile-brittle transition temperature (DBTT). This effect is due to the segregation of carbon to grain boundaries. Aging at 873 $\mathrm{K}$ of the quenched specimen with $0.52 \% \mathrm{P}$ and $0.0008 \% \mathrm{C}$ reduces DBTT and increases the degree of grain boundary segregation of carbon while it does not affect the degree of grain boundary segregation of phosphorus. The grain boundary segregation of carbon increases the grain boundary cohesion and prevents the intergranular fracture without removing phosphorus from grain boundaries.

DBTT's of the Fe-P-C alloys are analyzed in terms of the degree of grain boundary segregation of carbon and phosphorus and the solution hardening by phosphorus (the bulk concentration of phosphorus). The site-competition between carbon and phosphorus is taken into account in the calculation of the degree of segregation. It is found that the increase in the boundary cohesion by the carbon segregation is an important factor to prevent IGF.

\section{1. 緒}

\section{言}

りんは，自動車用高張力鋼板においては，その強度と 加工性を改善するために有用な元素として利用されてい る1)。この鋼板に扐いては，良好な加工性を得るため 飞，炭素は通常 $0.01 \%$ 以下に下げられている。 しか し，あまりに炭素量を減らすと，粒界破壞（IGF）がお こるようになつて, 鋼はかえつて脆くなる2)。この脆化 現象は Fe-P-C 合金に招いてもシャルピー衝撃試験で 見出されている3)．オージェ電子分光法 (AES) によつ て, 粒界に偏析した炭素が, 同じく粒界に偏析したりん による IGF を抑制することが明らかとなつた2)3)。そこ で，りんをさらに有用な元素として利用するには，炭素 による IGF 抑制効果の機構を解明することがのぞまれ る.

著者らは前報に打いて，炭素の IGF 抑制効果に対し て, 三つの機構を検討しだ)。その一つはサイトコンペ ティション効果（以後 SG 効果と略記する）である. り ん原子と炭素原子とは粒界で偏析する場所が共通である とし，炭素が偏析するとその分だけりんの偏析が減り IGF が抑制されると考学る. ERHART と GRABKE4) およ
び著者ら ${ }^{5)}$ は, AES により Fe-P-C 合金でのりんと炭 素との平衡粒界偏析を調べ, 試料中の炭素濃度を增すと りんの偏析量が減少することを示した. この現象は SC 効果で説明できる. しかし，IGF の程度がりんの偏析 量のみによるとは言いきれないし，りんの偏析量の低下 だけで IGF の抑制がすべて説明できるとは言いきれな い. 第 2 の機構は化学的相互作用説である.ここでは, 粒界で炭素原子がりん原子の結合の様子を変えて, 鉄の 粒界結合力に対するりんの負の作用が打ち消され，また は軽減されると考える。この説では, 粒界での炭素とり んの間に相互作用のあることが仮定されている.最後の 機構は, りんの偏析とは無関係に, 粒界に偏析した炭素 が鉄の粒界結合力を大きくするというすのである.

前報》)で著者らは，この第 3 の仮説がもつとも確から しいことを述べた，しかし，前報においては，延性脆性 遷移温度 (DBTT) の定量的な議論において, SC 効果 を正しくとり入れてなかつた．本研究においては，りん と炭素の量を前報の研究に打けるよりる幅広く変えて, SC 効果を正しく考虑することにした．両元素の粒界偏 析を, 両元素の含有量を变え, また二つの温度から急冷 することによつて変化させた。偏析量は AES で測定し

昭和 59 年 3 月 14 日受付 (Received Mar. 14，1984)

* 東北大学金属材料研究所 工博 (The Research Institute for Iron, Steel and Other Metals, Tohoku University, 2-1-1 Katahira Sendai 980)

*2 東北大学大学院 (現: (株) 東芝) (Graduate School, Tohoku University, Now Toshiba Corporation) 
た．勒性と破壊様式，硬度および結晶粒度を調べた。こ れらの結果から炭素の IGF 抑制効果の機構を検討し た.

\section{2. 実 験 方 法}

\section{$2 \cdot 1$ 試料作製}

電解鉄（東邦亜鉛，マイロン)， $\mathrm{Fe}-25 \mathrm{wt} \% \mathrm{P}$ 合金， $\mathrm{Fe}-4.5 \mathrm{wt} \% \mathrm{C}$ 合金を用いて合金を溶製した． Fe-25\% $\mathrm{P}$ 合金は市販のものを購入し再溶解して純化した． Fe$4.5 \% \mathrm{C}$ 合金は, アルゴン雾囲気中で電解鉄を高純度る つぼを用いて溶解することで作製した。

まず酸化カルシウムるつぼ中で $5 \mathrm{~kg}$ の電解鉄を真空 溶解し、これに $\mathrm{Fe}-4.5 \% \mathrm{C}$ 合金を加えて脱酸した. そ れに $\mathrm{Fe}-25 \% \mathrm{P}$ 合金を加えて Fe-P-G 合金とした．脱 酸の際に残留した炭素をあつて合金成分としたのであ る.鋳塊を, $1373 \mathrm{~K}$ から $1073 \mathrm{~K}$ の間で, 鍛造および 压延によつて $6 \mathrm{~mm} \times 6 \mathrm{~mm}$ の角棒とした。この棒から， シャルピー衝撃試験片 $(4 \mathrm{~mm} \times 4 \mathrm{~mm} \times 55 \mathrm{~mm})$, および AES 試片 (3.6 mm $\phi \times 32 \mathrm{~mm}$ 長) を切り出した.

Table 1 に合金の化学分析値を示す.この試料に 973 K での湿水素・乾水素処理を施して炭素量を変えた. 処理時間と得られた残留炭素量を Table 2 に示す.

すべての試料は, 約 $1 \times 10^{-4}$ torr の真空中で $1073 \mathrm{~K}$ に $1 \mathrm{~h}$ 加熱後, そのまま $273 \mathrm{~K}$ の油に急冷された。一 部の試料は,さらに $873 \mathrm{~K}$ に加熱され, $273 \mathrm{~K}$ の水中 に急冷された。

\section{2 機械的性暂と AES の測定}

機械的性質としては, シャルピー衝撃值とビッカース

Table 1. Composition of the Fe-P-C alloys in wt $\%$.

\begin{tabular}{cccccc}
\hline & $\mathrm{P}$ & $\mathrm{C}$ & $\mathrm{O}$ & $\mathrm{Si}$ & $\mathrm{Mn}$ \\
\hline \hline $\mathrm{Fe}-0.11 \mathrm{P}$ & 0.11 & 0.036 & 0.0007 & 0.012 & 0.003 \\
\hline $\mathrm{Fe}-0.34 \mathrm{P}$ & 0.34 & 0.040 & 0.0032 & 0.007 & 0.005 \\
\hline $\mathrm{Fe}-0.52 \mathrm{P}$ & 0.52 & 0.022 & 0.0088 & 0.021 & 0.013 \\
\hline $\mathrm{Fe}-0.67 \mathrm{P}$ & 0.67 & 0.024 & 0.0010 & 0.026 & 0.017 \\
\hline
\end{tabular}

Table 2. Conditions of decarburization and the residual carbon concentration in wt \%*.

\begin{tabular}{cccccc}
\hline & $1 \mathrm{~W}+1 \mathrm{D}^{* *}$ & $2 \mathrm{~W}+2 \mathrm{D}$ & $5 \mathrm{~W}+5 \mathrm{D}$ & $12 \mathrm{~W}+5 \mathrm{D}$ & $17 \mathrm{~W}+7 \mathrm{D}$ \\
\hline \hline $\mathrm{Fe}-0.11 \mathrm{P}$ & 0.018 & 0.011 & 0.002 & 0.0014 & 0.0010 \\
\hline $\mathrm{Fe}-0.34 \mathrm{P}$ & & 0.010 & 0.002 & 0.0014 & 0.0010 \\
\hline $\mathrm{Fe}-0.52 \mathrm{P}$ & 0.012 & 0.008 & 0.0021 & 0.0010 & 0.0008 \\
\hline $\mathrm{Fe}-0.67 \mathrm{P}$ & 0.015 & 0.011 & 0.004 & 0.0023 & 0.0018 \\
\hline
\end{tabular}

* For some specimens, the carbon concentration is given down to $1 \mathrm{ppm}$. The analysis was done carefully and repeated several times. Values in the table are the average. The scatter of data is given by error bars in Fig. 1 .

** $m \mathrm{~W}+n \mathrm{D}$ indicates the decarburization for $m \mathrm{~h}$ in wet hydrogen (W) and for $n \mathrm{~h}$ in dry hydrogen (D).

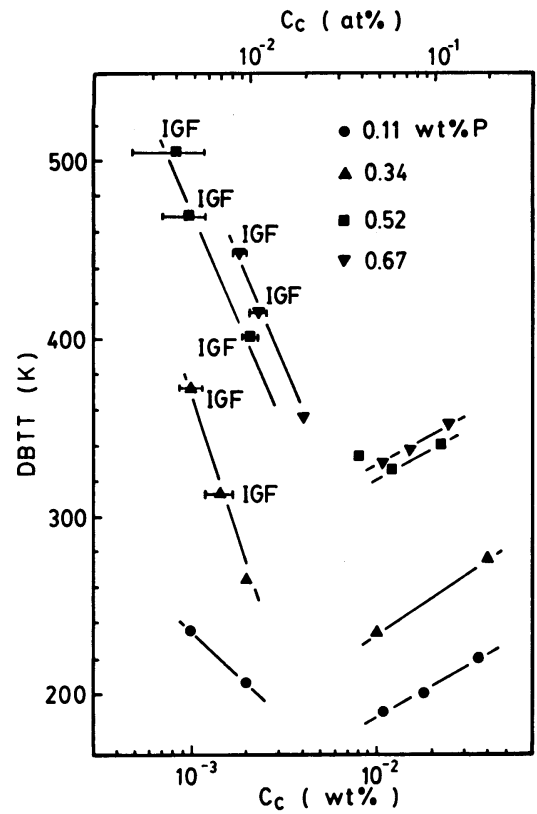

Fig. 1. Effect of carbon on the ductile-brittle transition temperature (DPTT) of Fe-P alloys. IGF means that the specimen showed the intergranular fracture.

硬度を測定した．DBTT は，衝撃吸収ェネルギー温度 線図で，上下のしきい値の中間の值に相当する温度をと つた．延性一脆性遷移はかなり狭い温度範囲でおこるの で, DBTTは $\pm 10 \mathrm{~K}$ の範曲できめることができ, 定 量的な検討が可能である. りん拈よび炭素の粒界偏析量 は, PHI 590 走査型オージェ電子分光装置で測定した. 分析器の真空度は, 試料破断および分析の間, 約 $5 \times$ 10-11 torr に保たれた．したがつて測定中に破面が污染 されることはなかつだ).

\section{3. 実 験 結 果}

\section{1 急冷試料の機械的性积}

Fig. 1 は, Fe-0.11, 0.34, 0.52, 0.67\% P 合金につ いて, 全炭素量と DBTT との関係を示す. これらの試 料は $1073 \mathrm{~K}$ で $1 \mathrm{~h}$ 加熱後 $273 \mathrm{~K}$ の油中に急冷したも のである．粒界破壊した試料は図中に IGF の記号を付 した†。約 $0.01 \%$ またはそれ以下の炭素を含む試料は フェライト単相であり，0.02\% またはそれ以上の炭素 を含むものでは, パーライト・ノジュールがみられた。

†本研究では $0.1 \% \mathrm{P}$ 合金は粒界破埴しないが，前報》の研究では低炭 素 $-0.1 \% \mathrm{P}$ 合金は粒界破液した。 また，全般的に，本研究での DB TT は前報での值より低い。乙れらの相違は, 両研究に用いられた試 料中の炭素, りん以外の不純物の種類と量が異なるためであると考え られる. 


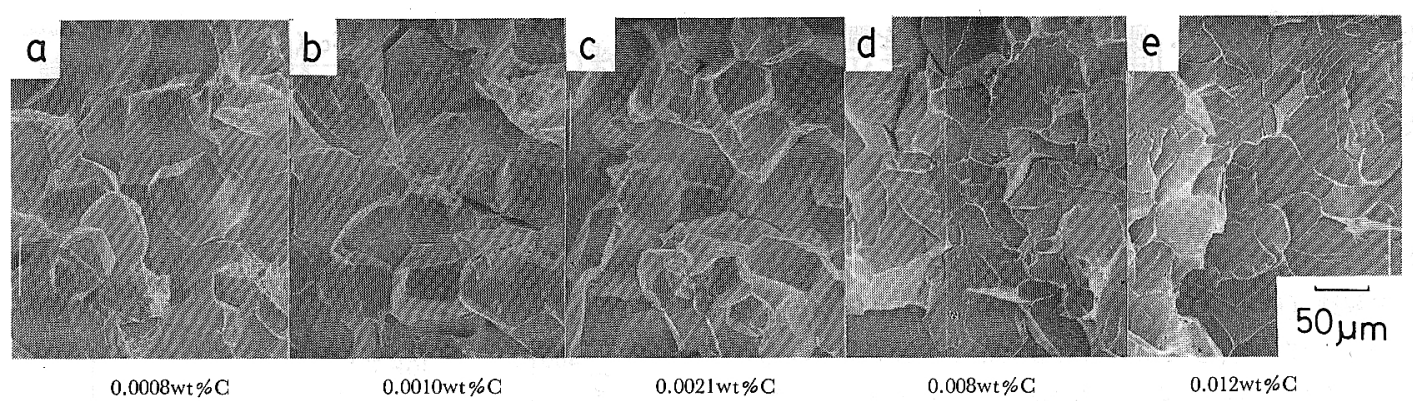

Photo. 1. Effect of carbon on the mode of fracture in Fe-0.52\% $\mathrm{P}$ alloys. The testing temperature is below DBTT in each specimen.

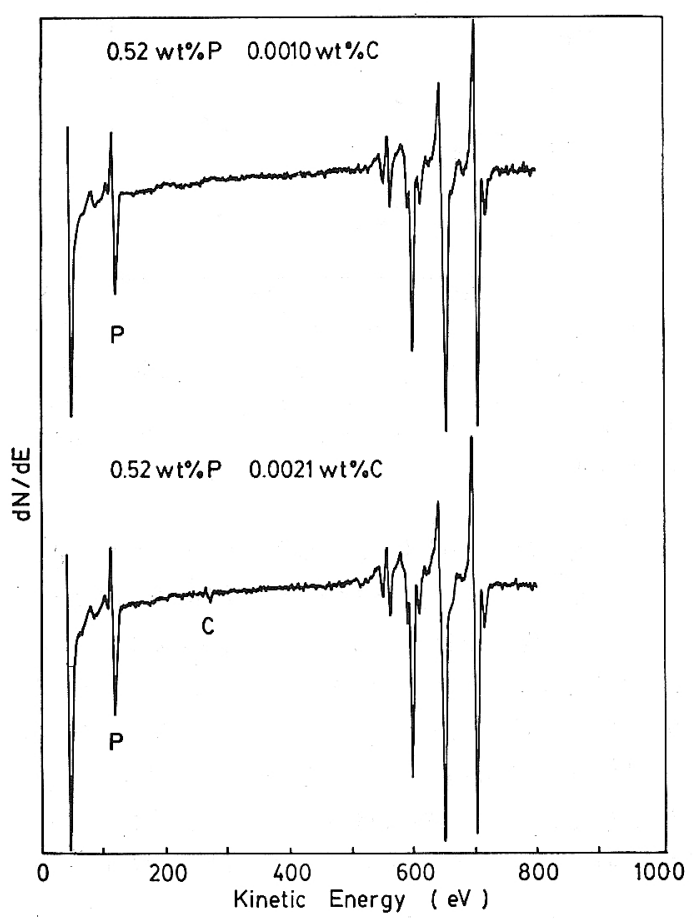

Fig. 2. Auger electron spectroscopy of grain boundary facet revealed by fracture of $\mathrm{Fe}-0.52 \%$ $\mathrm{P}-\mathrm{C}$ alloys.

このパーライトが， $0.02 \% \mathrm{C}$ 以上での $\mathrm{DBTT}$ の上昇の

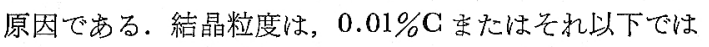
ASTM 番号 5 で, $0.02 \% \mathrm{C}$ 以上では炭素量が増すほど 結晶粒が細かくなつた，0.01\% またはそれ以下の炭素 を含む $0.34,0.52,0.67 \% \mathrm{P}$ 合金のビッカース硬度は， それぞれ 130, 160,180であつた. Photo. 1 は，DBTT 以下の温度で $\mathrm{Fe}-0.52 \% \mathrm{P}$ 合金を衝撃試験したときの， 破壊様式に対する炭素の影響を示す，低炭素試料に和い ては，粒界破買が主である。Fig. 2 は，0.52\% P 合金 についての AES の結果を示す。 $0.0010 \% \mathrm{C}$ の試料の粒 界破面からのオージェスペクトルには炭素のピークはは

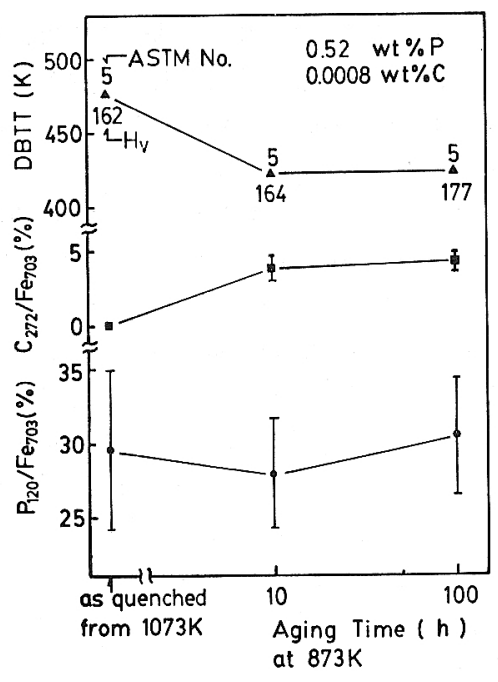

Fig. 3. Effect of aging at $873 \mathrm{~K}$ on DBTT and the degree of segregation of carbon and phosphorus in $\mathrm{Fe}-0.52 \% \mathrm{P}-0.0008 \% \mathrm{C}$ alloys quenched from $1073 \mathrm{~K}$. ASTM number and the Vickers hardness are shown on the DBTT data.

とんどみられないが，0.0021\%G を含むものでは炭素の ピークがはつきりと認められる. Fig. 1 牤よび 2 亿示 す結果は，0.01\% なでは，炭素の添加によつて IGF が 抑制されて DBTT が低下すること，そしてこの IGF を抑制する效果は粒界偏析した炭素によることを示して いる.

\section{2 時効した試料の機械的性質と AES}

Fig. 3 Kは， Fe-0.52\% P-0.0008\% C 合金の DBTT とりん特よび炭素の粒界偏析量が， $873 \mathrm{~K}$ の時効でどら 変わるかを示してある. AES のデータのばらつきは, 偏析量の粒界面方位依存性 ${ }^{5) 6)}$ によるものであつて, 測 定そのむののばらつきではない.データの相対的なばら つきの程度は, りんでも炭素でも同程度である. 試料は はごめ $1073 \mathrm{~K}$ K $1 \mathrm{~h}$ 加熱されて $273 \mathrm{~K}$ に急冷されて いるが, $1073 \mathrm{~K}$ はこの合金のフェライトの領域の温度 
である. $873 \mathrm{~K}$ の時効によつて DBTT が低下している が，破壊様式はすべての試料に打いて 90\% 以上の粒界 破面率を示す. りんの偏析量, 硬度, 粒度は $873 \mathrm{~K}$ 加 熱によつて変化しないが, 炭素の偏析量が增加してい る.この結果は, 炭素が粒界に偏析すれば, りんを粒界 から追い出すことがなくても，粒界結合力が増加して IGF が抑制されることをはつきりと示している.

SC 効果があるのに, 炭素の偏析が增加してりんの偏 析が減少しないのはどうしてかといら疑問があろう。こ れは時効温度をらまくえらんだためである。この場合， 炭素との SC 効果でりんの偏析量が減少する分を温度の 低下による偏析量の増加で補つているということが計算 で示される5).

\section{4. 考察}

\section{1 岸素およびりんの何析の DBTT への奇与}

Fig. 3 の結果は, SC 効果が DBTT 飞対する炭素の 効果の唯一の機構ではないことを示している. しかしま た, この結果は, 炭素の効果の原因として SC 効果によ る機構を全く除外するものでもない，粒界での炭素とり んの間には，たしかに SC 効果がある゙)。そこで，Fig. 1 に示した DBTT の変化に対して SC 効果がどれだけ 寄与しているか, また炭素の粒界偏析量の増加そのもの がどこまで寄与しているかを調べる必要がある。

以下では, 炭素拈よびりんの偏析の DBTT 変化への 寄与を見積もるために, 両元素の粒界被覆率を計算し て, 実験的に求められた DBTT 変化と比較する. りん および炭素の粒界被覆率 ${ }^{\dagger}, n_{\mathrm{P}}^{G B}, n_{\mathrm{C}}^{G B}$, は次式で与えら れる。

$$
\begin{array}{r}
n_{\mathrm{P}}^{G B}=\frac{n_{\mathrm{P}} \exp \left(\frac{\Delta E_{\mathrm{P}}}{k T}\right)}{1+n_{\mathrm{P}}\left(\exp \left(\frac{\Delta E_{\mathrm{P}}}{k T}\right)-1\right)+n_{\mathrm{C}}\left(\exp \left(\frac{\Delta E_{\mathrm{P}}}{k T}\right)-1\right)} \\
n_{\mathrm{C}}^{G B}=\frac{n_{\mathrm{C}} \exp \left(\frac{\Delta E_{\mathrm{C}}}{k T}\right)}{1+n_{\mathrm{P}}\left(\exp \left(\frac{\Delta E_{\mathrm{P}}}{k T}\right)-1\right)+n_{\mathrm{C}}\left(\exp \left(\frac{\Delta E_{\mathrm{C}}}{k T}\right)-1\right)}
\end{array}
$$

ここで $n_{\mathrm{P}}, n_{\mathrm{C}}$ はりんおよび炭素の全濃度である5)。 ん拉よび炭素の偏析エネルギー, $\Delta E_{\mathrm{P}}$ 打よび $\Delta E_{\mathrm{C}}$ はそ れぞれ $50 \mathrm{~kJ} / \mathrm{mol}$ 和よび $80 \mathrm{~kJ} / \mathrm{mol}$ と推定されてい る7)8). (1), (2)式に沶いては, りんと炭素の間の SC

$\dagger^{2}$ ことで粒界被夏率とは，偏析の能和值に対する割合を示すもので， 粒界での偏析元素の灌度ではない.りんの飽和偏析値は, 破壊によ つてあらわれた粒界面のひとつについて 25 at\% である ${ }^{6)}$. 炭素 の钧和偏析値も 25 at\% と仮定した.

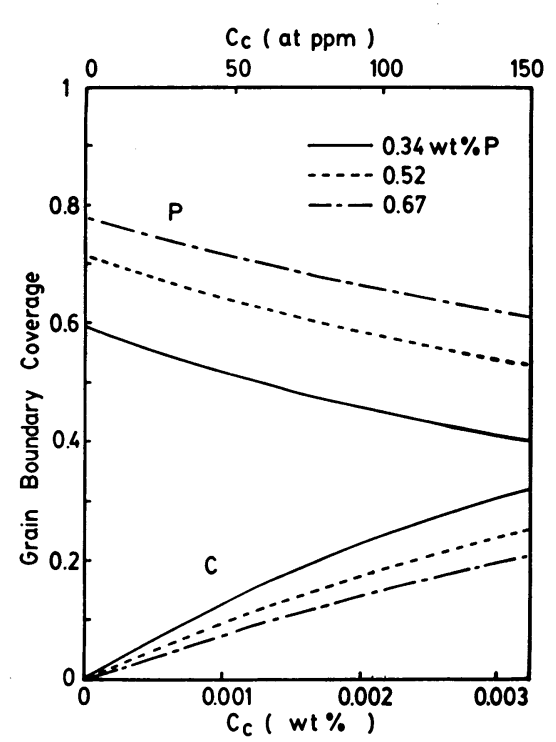

Fig. 4. Calculated grain boundary coverage of phosphorus and carbon in Fe-P-C alloys. The calculation was made with the segregation energies of phosphorus and carbon of 50 and $80 \mathrm{~kJ} / \mathrm{mol}$, respectively, and $T=1073 \mathrm{~K}$.

効果が考虑されている.すなわち, りんと炭素とは粒界 上で共通の場所を占めるとしている. Fig. 4 は，(1)， (2)式によつて $1073 \mathrm{~K}$ に対して計算された $n_{\mathrm{P}}^{g B}, n_{\mathrm{C}}^{g B}$ を示す.この值を用いて実験結果を解析するに当たつて は, DBTTと $n_{\mathrm{P}}^{G B}$ および $n_{\mathrm{C}}^{G B}$ の間には一次の関係の あることを仮定した．この仮定が妥当であることはすで に前報に示してある3).

(1) 炭素の偏析による DBTT の変化

$n_{\mathrm{C}}^{G B}$ の変化による DBTT の変化率を, Fig. 3 亿示 した時効の実験結果から推定することができる.それ は, $873 \mathrm{~K}$ に护ける時効は炭素の偏析量を変えるだけ で，DBTT の变化を抗こすような他の因子，すなわち りんの偏析量や結晶自身の塑性的性質 (硬度), 結晶粒度 は影響をうけないからである. $873 \mathrm{~K}$ 時効した合金の $n_{\mathrm{o}}^{G B}$ は, 観測された AES 炭素ピークの大きさと炭素オ 一ジェ電子の相対感度とから， $0.17 \pm 0.02$ と推定され る. 一方, (2)式から $n_{\mathrm{C}}^{G B}=0.18$ 之計算され, 測定値 とよく一致する. 時効前の $n_{\mathrm{C}}^{G B}$ 值は, オージェピーク が 観察されないので, 求められないが, (2)式からは, 0.07 と計算される. したがつて，時効による $n_{\mathrm{C}}^{G B}$ の 変化は, 0.11 と推定される.この $873 \mathrm{~K}$ 時効による DBTT の変化は $60 \mathrm{~K}$ (Fig. 3) であるから, 炭素の偏 析量の变化による DBTT の変化率は $n_{\mathrm{P}}^{G B}$ 一定の 条件 下で, $-550 n_{\mathrm{C}}^{G B}(\mathrm{~K})$ となる. 
（2）りんの偏析による DBTT の変化と, SC 効果 の DBTT への寄与

$n_{\mathrm{P}}^{G B}$ の変化による DBTT の変化の割合は, Fig. 1 の結果から推定できる.りん量一定の各合金系に打い て, DBTT は全炭素量すなわち $n_{\mathrm{c}}$ が增加すると低下 する.ここでの組成範囲では, 硬度はりん量できまり, 炭素量にはほとんど依存しない3)。したがつて, DBTT の低下は $n_{\mathrm{C}}^{G B}$ の増加それ自身と，それにともなつて和 こる SC 効果による $n_{\mathrm{P}}^{G B}$ の低下とによる. $0.52 \% \mathrm{P}$ 合 金に拀いては, $n_{\mathrm{C}}$ が $0.0008 \%$ から $0.0021 \%$ まで増加 すると, DBTT は $510 \mathrm{~K}$ から $410 \mathrm{~K}$ に低下する。こ の時の $n_{\mathrm{C}}^{G B}$ の増加は, (2)式によつて, 0.07 から 0.17 と計算される. 前節で推定した結果から,この 0.10 の $n_{\mathrm{C}}^{G B}$ の変化それ自体によつて, DBTT は $55 \mathrm{~K}$ 低下寸 ることになる. 実験では DBTT の低下は $100 \mathrm{~K}$ であ る. $n_{\mathrm{o}}$ の増加によつて生ずる $n_{\mathrm{C}}^{G B}$ の増加だけでは, 測 定された DBTT の変化は約半分しか説明できない. 残 りの $45 \mathrm{~K}$ は, SC 効果によつて $n_{\mathrm{P}}^{G B}$ が減少することに よつて説明されなければならない（1)式によれば, 上 述の $n_{\mathrm{C}}$ の増加によつて, $n_{\mathrm{P}}^{G B}$ は 0.66 から 0.58 に減 少することになる.これだけの $n_{\mathrm{P}}^{G B}$ の減少で DBTT が $45 \mathrm{~K}$ 低下するのであるから，りんの偏析による DBTT の変化率は $560 n_{\mathrm{P}}^{G B}$ となる. 同様に, $0.52 \% \mathrm{P}$ 合金につ いて $0.0010 \% \mathrm{C}$ と $0.0021 \% \mathrm{C}$ とを比べることで, 380 $n_{\mathrm{P}}^{G B}$ を得る. この場合には, DBTT の変化は $60 \mathrm{~K} て ゙$, $n_{\mathrm{C}}^{G B}$ の変化はそのうちの $38 \mathrm{~K}$ に対応する. $\mathrm{SC}$ 効果寄 与は $22 \mathrm{~K}$ で, DBTT の全変化量の約 $1 / 3$ である. 平 均して, $0.52 \% \mathrm{P}$ 合金については $(470+90) n_{\mathrm{P}}^{G B}$ とな る.

同じような計算を, $0.67 \% \mathrm{P}$ 合金, $0.34 \% \mathrm{P}$ 合金につ いて行つて, それぞれ $200 n_{\mathrm{P}}^{G B}, 1100 n_{\mathrm{P}}^{G B}$ といら值を得 た. DBTT の全変化量に対する SC 効果の寄与は, そ れぞれ $20 \%, 60 \%$ である.この両合金系 $(0.67 \% \mathrm{P}$ と $0.34 \% \mathrm{P})$ に対する $\mathrm{SG}$ 効果の推定值は, 二つの実験結 果から計算したもので， $0.52 \% \mathrm{P}$ 合金に対する值に比べ て信頼度は低い。こうした測定上の不確定さを考虑し た上で，SC 効果の寄与は，炭素量が増すことによる DBTT 低下量の半分以上にはならないと結論してよい だろう.りんの偏析の効果として, 以後の計算では 0.52 $\% \mathrm{P}$ 合金に対する値, $470 n_{\mathrm{P}}^{G B}$ を用いることとする.

\section{2 岸素の倔析による粒界結合力增加の機模}

炭素の粒界偏析それ自体が IGF を抑制する。すなわ ち粒界に偏析した炭素は粒界結合力を増加するといらこ とを示したが，この炭素の効果の機構として二つの仮説 が考えられる. その 1 は炭素とりんの化学的相互作用で
あり, 第 2 は炭素そのものの強化作用である.

(1) 化学的相互作用仮説

化学的相互作用仮説では, 粒界偏析したりんが鉄の粒 界結合力を低下させる作用を, 同じく粒界に偏析した炭 素が打ち消すと考えるるので, 粒界でのりんと炭素の間 に化学的結合力を想定している.この仮説は次のような 理由で成り立たないと思われる. 第一に，りんと炭素の 間に結合的相互作用は見出されていない，逆に，溶鉄中 の活量測定ではりんと炭素の間には反発相互作用が認め られている9)。溶鉄での結果がそのまま固体，すなわち 溶質原子のまわりの弾性歪みを無視できない場合, につ いてもそのままあてはまるとは言えないが，この活量測 定の結果は本仮説には不利である.

$n_{\mathrm{P}}^{G B}, n_{\mathrm{C}}^{G B}$ の変化湾よる DBTT の变化率をさきに推 定したが，この結果も本仮説には不利である.りんの偏 析の寄与は $470 n_{\mathrm{P}}^{\text {G }}$ であつた。 もしも炭素原子 1 個がり ん原子 1 個を無害化するとし，また，りんと炭素の間の 結合を仮定するにしてもとれは小さいと考えれば, 炭素 によつて無害化されるりんの偏析量は $n_{\mathrm{P}}^{G B} \cdot n_{\mathrm{C}}^{G B}$ となり, 炭素の偏析による DBTT 変化は, $-470 n_{\mathrm{P}}^{G B} \cdot n_{\mathrm{C}}^{G B}$ とな る. Fig. 4 に示したように, 本研究の範囲では $n_{\mathrm{P}}^{G B}$ は 約 0.7 であるから, 偏析炭素の寄与は $-330 n_{\mathrm{C}}^{G B}$ とな る. 一方, $873 \mathrm{~K}$ 時効の実験からは $-550 n_{\mathrm{C}}^{G^{B}}$ が得られ ており,これと一致しない。この問題を解くもら一つの 方法として，りん量の異なる合金中での炭素の効果を調 ベることが考えられる.もし本仮説が正しいなら，偏析 炭素の DBTT への寄与はりん量によるはずだからであ る. しかし本研究では, データの精度が十分でなく, そ こまでの検討はできなかつた.

\section{(2) 炭素それ自体のもつ強化作用}

現在のところ, 炭素の作用の機構としては, 炭素自体 が粒界結合力を強めていると考えるのがもつとも妥当で あろう. 現在，この考方方を直接佂明することはでき ないが，りんとの相互作用が否定されれば残る考え方は これしかない。

りんの偏析以外の原因で IGF がおこることがある が, その場合でる炭素の偏析が IGF を抑制するという 例が少なくとも二つある.ひとつは純モリブデンの粒界 破壊が炭素の偏析によつて抑制されるといらことで10), もらひとつは水素による鉄の粒界破壊の炭素による抑制 効果である11). 木村と木村は10), 高純度鉄に水素を電解 チャージしながら $170 \mathrm{~K}$ で引張つた時に括こる IGF が, 約 80 at. ppm の炭素を添加して $923 \mathrm{~K}$ から急冷 (炭素を固溶させる)すると抑制されることを見出した. これは炭素の粒界偏析による.この結果も, 炭素と水素 
の粒界での相互作用では説明できず，炭素独自の粒界結 合力強化作用と考えるのが妥当である. このことを次に 示そら†3. 彼らの試料は $1073 \mathrm{~K}$ から急冷されており， 炭素の粒界被覆率はその偏析熱から 0.05 以下と計算さ れる. 一方水素の粒界被覆率は 1 に近い. 水素は $170 \mathrm{~K}$ でる十分な易動度を有するので, この温度での平衡偏析 が実現される. また, 水素の偏析熱は転位と水素との結 合エネルギー $27 \mathrm{~kJ} / \mathrm{mol}^{12)}$ と同じくらいと考えてよい. 粒内に固溶する水素量の推定は困難であるが, 水素透過 の実験結果などを総合して判断すると, $20 \mathrm{~A} / \mathrm{m}^{2}$ という 電解条件では, 10 at. ppm の程度と考えてよい. これら の值から $170 \mathrm{~K}$ での粒界破覆率はほぼ 1 と計算される. このように, 粒界での水素濃度は炭素濃度に比べてはる かに多い，それにもかかわらず炭素は水素による IGF を抑制する. もし炭素と水素の相互作用で炭素が水素の 粒界脆化作用を打ち消すのであれば, 炭素濃度は水素濃 度と同程度でなければならない。

このように, 炭素は IGF の原因が何であれ, また脆 化元素の偏析量によらず, 粒界結合力を高める作用を有 するのであるから，これは炭素の固有の作用と考えるべ きであろら。

この炭素の固有の粒界強化作用がどのような機構によ るのかは, 今のところわかつていない.この機構を論ず るには，まず IGF の過程を原子レベルで明らかにしな ければならない。また DBTT と不純物の粒界破覆率の 間の一次の関係も, 実験的なものにすぎない. 炭素の効 果の作用を解明するには, DBTT が偏析量や粒界結合 力とどういう関係にあるかを理論的に解明しなければな らない。これらの基本的な問題は未解決ではあるが, 炭 素の IGF 抑制効果を解明する上に, 本研究のような進 め方は合理的であり, 結論は少なくとも定性的に正しい と考えてよい.

\section{$4.3 n_{\mathrm{P}}^{G B}, n_{\mathrm{C}}^{G B}$ およびりんによる固溶硬化を用いての DBTT の現象铪的表現}

IGF のおこりやすさ, より具体的には DBTT, は粒 界結合力, 結晶の変形しやすさと結晶粒度できまる. 粒 界結合力は不純物の偏析によつて影響をらけるので, こ こでは $n_{\mathrm{P}}^{G B}$ と $n_{\mathrm{C}}^{G B}$ の DBTT への寄与を計算した. 他 の不純物，たとえば硫黄†4，の効果も考えなければなら ないが，ここではそれらは一定として扱う．また，本研 究では結晶粒度は一定である.したがつて，りんによる 固溶硬化の DBTTへの寄与を推定できれば, 本研究に

†3 この点は，木村と木村の原論交とはくわしく論じられていない.

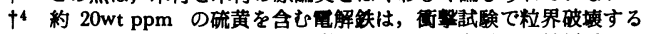
が，乙れに数 10 wtppm の炭素が入ると同じ条件では粒界破壊し なくなる。
用いた Fe-G-P 合金の DBTT を上述の各因子の関数 として表現できる.

固溶硬化の寄与は，炭素量を，たとえば $0.0010 \%+5$ と一定にして，りん濃度を変えた合金について DBTT を比較すれば求められる. $0.52 \% \mathrm{P}-0.0010 \% \mathrm{C}$ 合金と $0.34 \% \mathrm{P}-0.0010 \% \mathrm{C}$ 合金の DBTT の差は $100 \mathrm{~K}$ で ある (Fig. 1). このらち, りんと炭素の偏析量の変化 (Fig. 4 から，それぞれ $\Delta n_{\mathrm{P}}^{G B}=0.12, \Delta n_{\mathrm{C}}^{G B}=-0.04$ と 求められる.）による分は $470 \Delta n_{\mathrm{P}}^{G B}-550 \Delta n_{\mathrm{C}}^{G B}=78 \mathrm{~K}$ と なる. したがつて， $n_{\mathrm{P}}$ が $0.18 \mathrm{wt} \%$ 増加したことによ る固溶硬化の変化によつて, DBTT は $22 \mathrm{~K}$ だけ上昇 することになる.このようにして， $n_{\mathrm{P}}<0.5 \mathrm{wt} \%$ では， $1 \mathrm{wt} \%$ の $n_{\mathrm{P}}$ の変化による DBTT の変化率 (固溶硬 化分）を $120 \mathrm{~K}$ と推定できる.

一方，同様の計算を $0.67 \% \mathrm{P}$ 合金と $0.34 \% \mathrm{P}$ 合金の 組についても行つたところ, 固溶硬化の寄与はほとんど 0 となつた. この結果は, $n<0.5 \mathrm{wt} \%$ の場合の推定 值 $120 \mathrm{~K}$ といちじるしく異なる. この不一致の原因と しては，ひとつには測定点の数が十分でなく外挿が不正 確であることが考えられるが, 固溶硬化の DBTT への 奇与が $n_{\mathrm{P}}$ の大きくなるほど低下することも一因であろ う.すなわち, 粒界破壊エネルギーに対する結晶の変形 しやすさの寄与は, 粒界結合力が低下するほど小さくな る ${ }^{13)}$. したがつて， $n_{\mathrm{P}}$ が增すと粒界結合力は低下し， 結晶の変形しやすさが同じであつても粒界破壊中に粒界 にそつて扣こる塑性変形のエネルギーは低下する．した がつて, 固溶硬化の DBTT への寄与は $n_{\mathrm{P}}$ が大きくな るほど小さくなるであろう。このような理由から， $n_{\text {F }}$ と DBTT の間に線型の関係を仮定するのはよい近似で はない.ここでは，上述のような不確定さを念頭に拈い て, 固溶硬化の寄与を $100 n_{\mathrm{P}}\left(n_{\mathrm{P}}\right.$ は wt\%) とする.こ れは $n_{\mathrm{P}}<0.5 \mathrm{wt} \%$ の場合は大体よい近似であろう。こ のようにして, 本研究の範囲では,

$\operatorname{DBTT}(\mathrm{K})=470 n_{\mathrm{P}}^{G B}-550 n_{\mathrm{C}}^{G B}+100 n_{\mathrm{P}}+$ 定数 と表現できる， $n_{\mathrm{P}}$ は wt\% で与えられ，定数は計算值 と測定值が一致するように定める. Fig. 5 は，上式で の計算結果を実験と比較したものである．ほぼ良好な一 致が得られた. 定数項は $150 \mathrm{~K}$ である. 各因子の DB$\mathrm{TT}$ への寄与は非常に精確な値とは言えないし, 本研究 のりん，炭素濃度の範用を越えてこの式を適用すること はできない，しかし，この式から，各因子の DBTT へ の寄与がおよそどの程度であるかを概観することができ よう. 特に, 炭素の偏析それ自体が粒界結合力を高めて

†5 りん量の差による DBTT のちがいは，炭素量 $0.003 \%$ までは炭 素量にほとんど依存しない。 


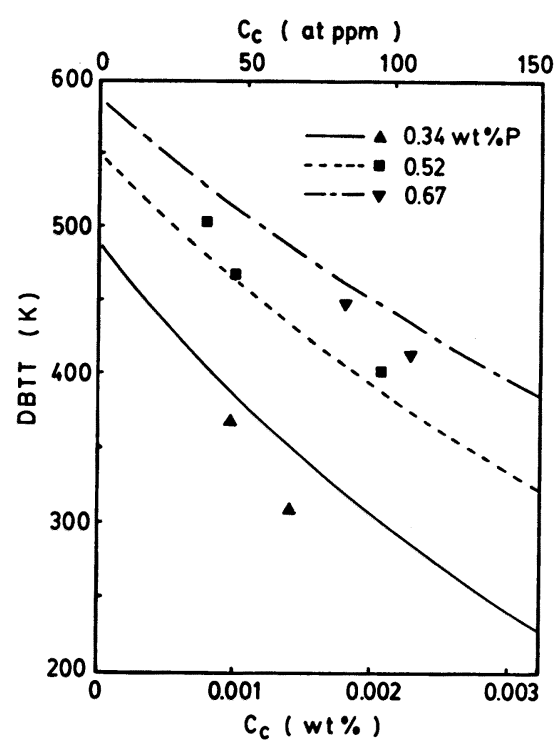

Fig. 5. DBTT calculated in terms of contributions of the grain boundary coverage of phosphorus and carbon and of the solution hardening. Experimental data are shown by squares and triangles.

いる効果の大きいことは注目すべきである.

ここで, DBTT に対する結晶の変形しやすさの寄与 について一言触れて抏こう，靱性に対する塑性の効果を 論ずるとさに，一般には常温で測定した硬度値を用い， 塑性変形の寄与を推定する。 しかし，DBTT が常温近 くにある時には, 常温での硬度值は, 衝撃試験との関連 で塑性を考えるための性質としては適当でない，それ は, 硬度測定とシャルピー衝撃試験では歪み速度がまつ たく異なり，一般には塑性は歪み速度に影響されるから である.したがつて上述の固溶硬化の DBTT への寄与 は全く実験結果を現象的に表現したものにすぎないこと を注意して拈こう。

\section{5. 結論}

延性一脆性遷移温度 (DBTT), ビッカース硬度, 結晶 粒度, 粒界破面率执よび炭素, りんの粒界偏析量を $\mathrm{Fe}$ P-G 合金について測定した（りん濃度は 0.11，0.34, $0.52,0.67 \%$, 炭素濃度は 0.0008 から $0.040 \%$ )。

結果は次のように要約される:

1. りん量 $0.67 \%$ までのこの合金を, フェライト領 域にある $1073 \mathrm{~K}$ から急冷した場合, DBTT は, 全炭 素量が 0.01\% までは, 炭素量の增加とともに低下す る. 炭素量がさらに増加すると DBTTはふたたび上昇 する.

2. $1073 \mathrm{~K}$ から急冷した試料においては， $0.52 \%$ お
よび, $0.67 \%$ のりんを含む合金において，炭素量が $0.0023 \%$ 以下のとき，また $0.34 \%$ りん合金では炭素量 $0.0014 \%$ 以下のとさ，粒界破壊がみられる. $0.11 \%$ り ん合金では粒界破壊はみられない.

3. $\mathrm{Fe}-0.52 \% \mathrm{P}-0.0008 \% \mathrm{C}$ 合金を $1073 \mathrm{~K}$ から急冷 し $873 \mathrm{~K}$ で時効したところ，りんの粒界偏析量は変化 せず, 炭素の粒界偏析量が増加し, DBTT が低下した. これは，粒界に炭素が偏析すること自体が粒界破壊を抑 制する効果をるつことを示すもので，炭素の偏析によつ てりんの偏析が減少することがなくても粒界破壊は抑制 される.

4. りん拉よび炭素量に対する DBTT の変化を, り ん扣よび炭素の粒界偏析量とりんによる固溶硬化量の項 で現象論的に表現した．粒界に偏析した炭素が粒界結合 力を増加させることが炭素の粒界破壊抑制作用のひとつ の重要な原因であることが示された.

本研究に用いられた電解鉄は東邦亚鉛株式会社より提 供されたものである．本研究に要した費用の一部は, 文 部省科学研究費総合研究拉よび新日本製鉄株式会社から の奖学寄付金によつた。ここに深甚の謝意を表する。

\section{交献}

1) H. Hu: Texture of Cryst. Sol., 2 (1976), p. 113 $H$. Hu: 同上, $4(1980)$, p. 13

松藤和雄，大沢紘一，酒匂雅隆：鉄と鋼，64 (1978)，S 722

小野 賢, 下村隆良, 大沢紘一，松藤和雄：鉄と 鋼, 67 (1981), S 457 武智 弘, 加藤 弘, 小山一夫, 川崎宏一, 豊田 洋民：鉄と鋼， 68 (1982)，p. 1355

2 ) 小西元幸, 小原隆央, 田中智夫, 大橋延夫, 大橋 善治：鉄と鋼，65 (1979), A97

3 ) $K$. Aвiko, $S$. Suzuki and $H$. Kimura: Trans. JIM., 23 (1982), p. 43

4) $H$. Erhart and H.J. Grabke: Met. Sci., 15 (1981), p. 401

5 ) S. Suzuki, $M$. Obata, $K$. Abiko and $H$. Kimura: Scripta Metall., 17 (1983), p. 1325

6 ) 鈴木 茂, 安彦兼次, 木村 宏: 鉄と鋼, 69 (1983), p. 625

7 ) $H . J$. Grabke, $W$. Panlitchke, $G$. Tauber and $H$. Viefhaus: Surf. Sci., 63 (1977), p. 377

8) J.Q. Clayton and J.F. Knott: Met. Sci., 16 (1982), p. 145

9 ) 萬谷志郎，丸山信俊，藤野伸司：鉄と鋼，69 (1983), p. 921

10) $S$. Suzuki, $H$. Matsui and $H$. Kimura: Mat. Sci. Eng., 47 (1981), p. 209

11）木村晃彦，木村 宏：日本金属学会誌, 47(1983), p. 807

12) J.P. Hirth: Metall. Trans., 11A (1980), p. 861

13) C.J. McMahon, Jr. and V. Vitek: Acta Metall., 27 (1979), p. 507 